\title{
A New Record of Sea Urchin (Echinoidea: Camarodonta: Strongylocentrotidae) Based on Morphological and Molecular Analysis in Korea
}

\author{
Taekjun Lee, Sook Shin* \\ Department of Life Science, Sahmyook University, Seoul 139-742, Korea
}

\begin{abstract}
Some echinoids were collected from the coast of Gangwon-do during the period from November 2008 to July 2011 and were identified on the basis of morphological characteristics and molecular analysis of cytochrome oxidase subunit I mitochondrial DNA. Among them, Strongylocentrotus pallidus (Sars, 1871) belonging to the family Strongylocentrotidae of the order Camarodonta is reported for the first time in Korea and is redescribed. The genetic differences ranged from 0.038 to 0.139 between S. pallidus and four other species of genus Strongylocentrotus, but ranged from 0.002 to 0.005 between Korean specimens and GenBank data of $S$. pallidus. This species is widely distributed in cold sea water along the western part of the North Pacific and the Northwest Atlantic.
\end{abstract}

Keywords: Echinoidea, sea urchin, Strongylocentrotus pallidus, cytochrome oxidase subunit I

\section{INTRODUCTION}

The genus Strongylocentrotus of the family Strongylocentrotidae consists of nine species globally (Smith, 2005; Kroh and Mooi, 2011): S. djakonovi, S. droebachiensis, S. franciscanus, S. intermedius, S. nudus, S. pallidus, S. polyacanthus, S. pulchellus and S. purpuratus. Among them, S. intermedius and S. nudus were reported in Korea (Shin and Rho, 1996; Shin, 1998, 2011). The former inhabits only the coast of East Sea but the latter inhabits all coastlines of South Korea except Jeju-do Island (Shin, 2011). Some echinoids were collected from Daejin to Imwon harbors in Gangwondo and were identified. Among them, S. pallidus is newly reported in Korea. Mortensen (1943) reported that morphological characteristics of $S$. pallidus were not distinctly distinguished from the adjacent species such as $S$. echinoides and S. sachalinicus. Recently, these two species were recorded as synonymous with $S$. pallidus by morphological and molecular evidences (Jensen, 1974; Tatarenko and Poltarous, 1992; Bazhin, 1998). Therefore, we examined thoroughly morphological characteristics of Korean Strongylocentrotus species and analyzed the molecular differences between Korean species and Genbank data of S. pallidus and then other adjacent species using cytochrome oxidase subunit I (COI) mitochondrial DNA (mtDNA).

\section{MATERIALS AND METHODS}

\section{Sample collection and identification}

The specimens of Strongylocentrotus were collected using fishing nets at depths of 50-190 m from nine coastal areas in Gangwon-do from November 2008 to July 2011 (Table 1). Specimens were preserved in $95 \%$ methyl alcohol, and their important morphological characters were photographed by light- and stereo-microscopes (Nikon Eclipse 80i, Nikon SMZ1000; Nikon Co., Tokyo, Japan). Identification of specimens referred to Mortensen (1943), Southward and Campbell (2006) and Shin (2011).

\section{DNA amplification and sequencing}

Genomic DNA was extracted from the gonad tissues of echinoids using by DNeasy blood and tissues kit (Qiagen, Hilden, Germany) and the COI gene was amplified using primers of Knott and Wray (2000): ECO1a (5'-ACCATGC AACTAAGACGATGA-3') and ECO1b (5'-GGTAGTCTG (c) This is an Open Access article distributed under the terms of the Creative Commons Attribution Non-Commercial License (http://creativecommons.org/ licenses/by-nc/3.0/) which permits unrestricted non-commercial use, distribution, and reproduction in any medium, provided the original work is properly cited.
*To whom correspondence should be addressed

Tel: 82-2-3399-1717, Fax: 82-2-3399-1729

E-mail: shins@syu.ac.kr 
AGTATCGTCGWG-3'). PCR amplification chemistry containing $1.5 \mu \mathrm{L}$ of genomic DNA, $2.5 \mu \mathrm{L}$ of $10 \times$ PCR buffer (contained $\mathrm{MgCl}_{2}$ ), $1.0 \mu \mathrm{L}$ of $2.0 \mathrm{mM}$ dNTPs and each primer, $0.3 \mu \mathrm{L}$ of nTaq DNA polymerase (Enzynomics, Seoul, Korea) and add up to $25.0 \mu \mathrm{L}$ with distilled water, and the following conditions: initial denaturation of $2 \mathrm{~min}$ at $95^{\circ} \mathrm{C}$, 30 cycles of $95^{\circ} \mathrm{C} 30 \mathrm{sec} ; 52^{\circ} \mathrm{C} 1 \mathrm{~min}$; and $72^{\circ} \mathrm{C} 1 \mathrm{~min}$ and a final elongation of $7 \mathrm{~min}$ at $72^{\circ} \mathrm{C}$. DNA fragments were sequenced on an ABI 3730XL sequencer (Applied Biosystems Inc., Forster City, CA, USA) using the ABI Prism Bigdye Terminator v3.1 (Applied Biosystems Inc.).

\section{Molecular data analysis}

The mitochondrial COI gene was mostly sequenced for this study, but the sequences data of four species which are not distributed in Korea obtained from GenBank (Table 2). COI

Table 1. Examined materials of Korean echinoids

\begin{tabular}{|c|c|c|c|}
\hline $\begin{array}{l}\text { Scientific } \\
\text { name }\end{array}$ & Date & Location/Depth & $\begin{array}{c}\text { No. of } \\
\text { specimens }\end{array}$ \\
\hline \multirow[t]{11}{*}{ S. pallidus } & 11 Aug. 2008 & Sacheon/100 m & 7 \\
\hline & 12 Nov. 2008 & Jangho/70 m & 3 \\
\hline & 27 Dec. 2009 & Gisamun/50 m & 7 \\
\hline & 17 Oct. 2010 & Daejin/150 m & 2 \\
\hline & 17 Oct. 2010 & Daejin/100 m & 8 \\
\hline & 18 Oct. 2010 & Namae/80 m & 12 \\
\hline & 24 Dec. 2010 & Geojin/120 m & 8 \\
\hline & 22 Jul. 2011 & Daejin/140 m & 7 \\
\hline & & Gonghyeonjin/120 m & 7 \\
\hline & 23 Jul. 2011 & Jumunjin/190 m & 6 \\
\hline & 24 Jul. 2011 & Imwon/50 m & 11 \\
\hline S. intermedius & 24 Jul. 2011 & Imwon/70 m & 2 \\
\hline S. nudus & 22 Jul. 2011 & Gonghyeonjin/120 m & 2 \\
\hline H. crassispina & 17 Jan. 2011 & Munseom/9 m & 3 \\
\hline
\end{tabular}

All collection sites locate in Gangwon-do except Jeju Island of $H$. crassispina. S., Strongylocentrotus; H., Heliocidaris. sequences were checked and aligned using by BioEdit v.7.0 (Hall, 1999) and genetic distances were calculated according to the Kimura 2-parameter model (Kimura, 1980) using by MEGA5 (Tamura et al., 2011). The phylogenetic relationship of the samples was drawn by using the neighborjoining (NJ), maximum-likelihood (ML) and Bayesian inference (BI). The NJ tree (Saitou and Nei, 1987) was inferred from Kimura 2-parameter genetic distance with bootstrapped 1,000 times using by MEGA5, and the ML analysis with the GTR+G model, determined with jModeltest 0.1.1 (Guindon and Gascuel, 2003; Posada, 2008), with 1,000 bootstrap replications using by PhyML v3.0 (Guindon and Gascuel, 2003) also BI analysis with same model and analyzed by MrBayes 3.1 with $1 \times 10^{6}$ generation repeats with the nucleotide model 4by4, Nst=6, rates = gamma, Ngammacat $=6$, and Burnin $=2.5 \times 10^{5}$ (Huelsenbeck and Ronquist, 2001; Ronquist and Huelsenbeck, 2003; Ronquist et al., 2005).

\section{RESULTS}

\section{Systematic notes}

Class Echinoidea Leske, 1778

Subclass Euechinoidea Bronn, 1860

Order Camarodonta Jackson, 1912

Infraorder Echinidea Kroh and Smith, 2010

Family Strongylocentrotidae Gregory, 1900

Genus Strongylocentrotus Brandt, 1835

\section{${ }^{1 *}$ Strongylocentrotus pallidus (Sars, 1871)}

Toxopneustes pallidus Sars, 1871: 25.

Strongylocentrotus pallidus Bidenkap, 1899: 112; Jensen, 1974: 119; Vader et al., 1986: 10; Southward and Campbell, 2006: 144; Kroh and Mooi, 2011: 124324.

Table 2. List of taxa included in this study, higher taxonomic placement and GenBank accession numbers for their gene sequences

\begin{tabular}{lll}
\hline \multicolumn{1}{c}{ Family } & \multicolumn{1}{c}{ Scientific name } & COI \\
\hline Echinometridae & Heliocidaris crassispina (A. Agassiz, 1863) & JN716400 \\
Strongylocentrotidae & Allocentrotus fragilis (Jackson, 1912) & HM473956 \\
& Strongylocentrotus droebachiensis (Müller, 1776) & HM542394 \\
& Strongylocentrotus intermedius (A. Agassiz, 1863) & JN716399 \\
& Strongylocentrotus nudus (A. Agassiz, 1863) & JN716398 \\
& Strongylocentrotus pallidus (Sars, 1871) (A) & JN716393 \\
& Strongylocentrotus pallidus (Sars, 1871) (B) & JN716395 \\
& Strongylocentrotus pallidus (Sars, 1871) (C) & JN716396 \\
& Strongylocentrotus pallidus (Sars, 1871) (D) & JN716397 \\
& Strongylocentrotus pallidus (Sars, 1871) (E) & HM543071 \\
& Strongylocentrotus pallidus (Sars, 1871) & EU700091 \\
\hline
\end{tabular}

Strongylocentrotus pallidus (A)-(E) were indicated in Table 3. COI, cytochrome oxidase subunit I. aObtained from GenBank. 

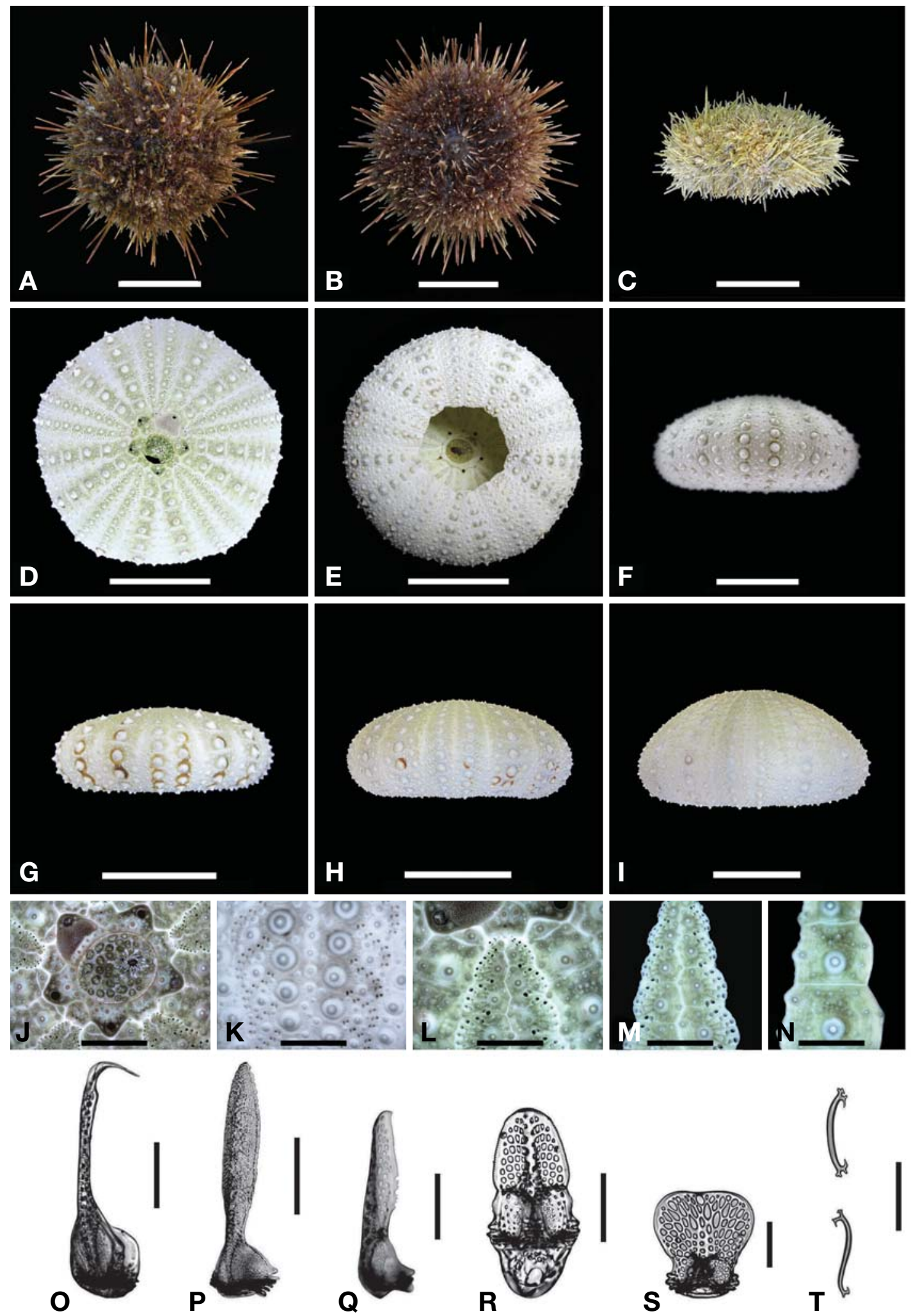

Fig. 1. Strongylocentrotus pallidus. A, Dorsal side; B, Ventral side; C, Lateral side; D, Dorsal side of denuded test; $E$, Ventral side of denuded test; F-I, Lateral side of denuded test; J, Apical system; K-M, Amburacral plates; N, Interamburacral plates; O, Globiferous pedicellaria; $\mathrm{P}, \mathrm{Q}$, Large and small tridentate pedicellaria; R, Ophiocephalous pedicellaria; $\mathrm{S}$, Triphyllous pedicellaria; $\mathrm{T}$, Spicules of tube-feet. Scale Bars: $A-I=2.5 \mathrm{~cm}, J-N=0.5 \mathrm{~cm}, O, P=300 \mathrm{~nm}, \mathrm{Q}, \mathrm{R}=200 \mathrm{~nm}, \mathrm{~S}, \mathrm{~T}=100 \mathrm{~nm}$. 
Table 3. Molphological characteristics of species of Strongylocentrotus in Korea

\begin{tabular}{|c|c|c|c|c|c|c|c|c|c|c|}
\hline & \multicolumn{5}{|c|}{ Size of test } & \multirow{2}{*}{$\begin{array}{l}\text { No. of } \\
\text { pore- } \\
\text { pairs }\end{array}$} & \multicolumn{2}{|c|}{ No. of plates } & \multicolumn{2}{|c|}{ Shape of test } \\
\hline & $\mathrm{D}(\mathrm{mm})$ & $\mathrm{H}(\mathrm{mm})$ & $P(m m)$ & $\mathrm{H} / \mathrm{D}(\%)$ & $\mathrm{P} / \mathrm{D}(\%)$ & & $\begin{array}{c}\text { Ambu- } \\
\text { racral } \\
\text { plate }\end{array}$ & $\begin{array}{l}\text { Interam- } \\
\text { buracral } \\
\text { plate }\end{array}$ & Horizonal & Vertical \\
\hline S. intermedius & $28.0-60.0$ & $14.0-35.0$ & $11.0-19.0$ & $47.0-51.0$ & $32.0-39.0$ & 5 & $25-40$ & $19-29$ & Circular & Hemispherical \\
\hline S. nudus & $20.0-100.0$ & $11.0-53.0$ & $9.0-32.0$ & $45.0-50.0$ & $36.0-41.0$ & 6 & $13-30$ & $11-19$ & Circular & Hemispherical \\
\hline S. pallidus & $43.0-59.0$ & $16.5-29.5$ & $14.5-19.7$ & $38.2-50.0$ & $31.6-35.7$ & 6 & $20-24$ & $14-16$ & $\begin{array}{l}\text { Roundly } \\
\text { pentagonal }\end{array}$ & $\begin{array}{c}\text { Flattened- } \\
\text { hemispherical }\end{array}$ \\
\hline (A) & 44.0 & 16.5 & 14.5 & 38.2 & 33.0 & 6 & 20 & 14 & " & Flattened \\
\hline (B) & 46.0 & 20.0 & 16.3 & 43.4 & 35.4 & 6 & 20 & 14 & $"$ & $\begin{array}{l}\text { Low } \\
\text { hemispherical }\end{array}$ \\
\hline (C) & 55.0 & 23.7 & 18.3 & 43.1 & 33.3 & 6 & 24 & 16 & $"$ & " \\
\hline (D) & 57.0 & 25.5 & 18.0 & 43.9 & 31.6 & 6 & 24 & 16 & $"$ & $"$ \\
\hline$(E)$ & 56.0 & 28.0 & 19.7 & 49.1 & 35.2 & 6 & 24 & 16 & $"$ & Hemispherical \\
\hline
\end{tabular}

(A)-(E) of S. pallidus used for the molecular analysis. Morphological data of $S$. intermedius and $S$. nudus are referred from Shin (2011). $D$, diameter; $H$, height; $\mathrm{P}$, peristome.

Strongylocentrotus drøbachiensis var. sachalinicus Döderlein, 1906: 517.

Strongylocentrotus echinoides A Agassiz and HL Clark, 1907: 122; HL Clark, 1912: 360; Mortensen, 1943: 219; Downey, 1968: 82.

Strongylocentrotus sachalinicus HL Clark, 1912: 353; Mortensen, 1943: 215; Kroh and Mooi, 2011: 513826.

Strongylocentrotus drøbachiensis sachalinica D'yakonov, 1938: 470, 496.

Key to the species of genus Strongylocentrotus in Korea

1. Ambulacral pore-pairs five in number …. S. intermedius Ambulacral pore-pairs six in number ………………….... 2

2. Primary spines long and stout …………............... S. nudus Primary spines short and not stout ………….... S. pallidus

Description. Test form vertically very variable (Table 3); flattened (Fig. 1G), low-hemispherical (Fig. 1F, H) and hemispherical forms (Fig. 1I). Outline of test roundly pentagonal forms (Fig. 1D). Margin of oral side slightly sunken towards peristome. Test of largest specimen $59 \mathrm{~mm}$ in diameter. Six ambulacral pore-pairs presented in an erected arc (Fig. 1KM). Madreporite has convexed form, larger than genital plates (Fig. 1J). Ocular plates composed five plates, three plates has pentagonal form, stuck between genital plates, like wedges, the other two plates have hexagonal form, situated between genital plates, bordering surnal parts. Surnal parts consist of numerous small plates, with anus situated beside center, surrounded with small blunt spines (Fig. 1J). Globiferous pedicellaria has single slender apical tooth, without lateral tooth (Fig. 1O). Tridentate pedicellaria has two different sizes, large and small form; large ones about five times larger than small one (Fig. 1P, Q). Ophiocephalous pedicellaria with fountain pore-pattern valves (Fig. 1R).
Triphyllous pedicellaria apple-like shaped, with upraised radial pore-pattern (Fig. 1S). Spicule of tube-foot usually elongated arch form, rarely twisted form, which has trifurcated end, of which inside node slender, tapered to tip (Fig. 1T).

Distribution. Korea (Gangwon-do), Japan (Siaukhu Bay), Bering Sea, Okhotsk Sea, North Pacific (Kuril island, Sakahlin), Northwest Atlantic (Norway, U.K.).

\section{Molecular analysis}

DNA sequence features. A total of 1,214 base pairs (bp) of the COI mtDNA were obtained from five specimens of Strongylocentrotus pallidus and the other Korean echinoids such as $S$. intermedius, $S$. nudus and Heliocidaris crassispina (Table 2). But, GenBank sequences were shorter than our sequences and so 818 bp COI mtDNA were analyzed in this study. In a group of $S$. pallidus, only 4 bp of the $818 \mathrm{bp}$ was different from each.

Phylogenetic tree. The phylogenetic relationships of the COI mtDNA from Strongylocentrotus species were analyzed by BI, ML and NJ method. We appointed Heliocidaris crassispina as the outgroup, and analyzed with $S$. droebachiensis, S. pallidus, S. polyacanthus and Allocentreotus fragilis obtained from GenBank. In the phylogenetic trees, $\mathrm{BI}, \mathrm{ML}$ and $\mathrm{NJ}$ analyses represented the non-discrimenatory phylogenetic branches (Figs. 2, 3). Korean specimens of $S$. pallidus coincident with $S$. pallidus of GenBank, and our phylogenetic reconstruction suggests that the genus Strongylocentrotus with A. fragilis is paraphyletic, but A. fragilis is closely related to $S$. pallidus and $S$. droebachiensis and its taxonomical position still obscure. Therefore the genus Strongylocentrotus without $A$. fragilis is monophyletic.

Genetic distances. Kimura 2-parameter genetic distance between Strongylocentrotus pallidus (Korea) and S. pallidus 


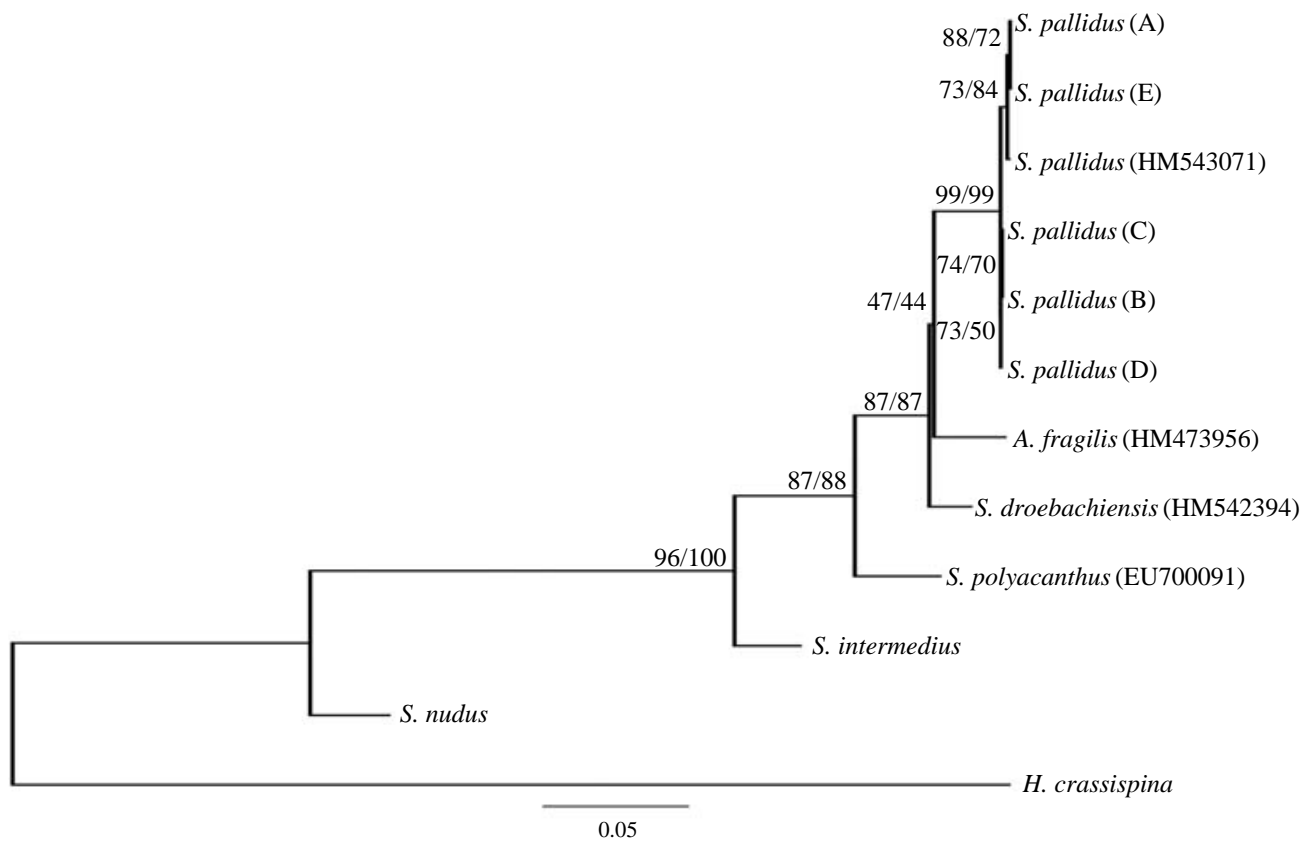

Fig. 2. Maximum likelihood $(\mathrm{ML})$ and neighbor joining $(\mathrm{NJ})$ combined tree generated from the COI mtDNA dataset. Node values following ML/NJ. S., Strongylocentrotus; A., Allocentrotus; H., Heliocidaris; COI, cytochrome oxidase subunit I; mtDNA, mitochondrial DNA.

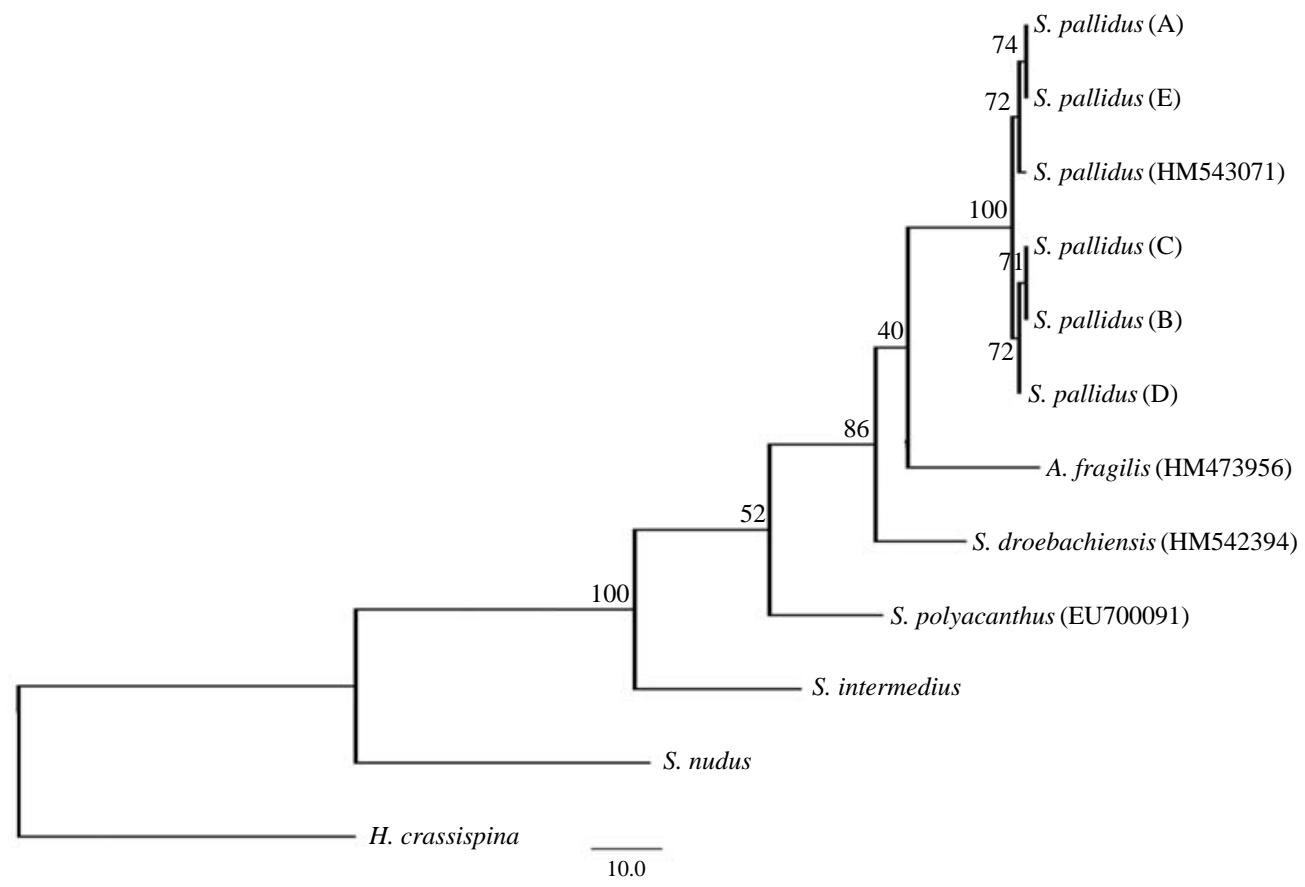

Fig. 3. Bayesian inference (BI) tree generated from the COI mtDNA dataset. S., Strongylocentrotus; A., Allocentrotus; H., Heliocidaris; COI, cytochrome oxidase subunit I; mtDNA, mitochondrial DNA.

(GenBank) ranged from 0.002 to 0.005 (Table 4). Pairwise ( $p$ ) distance average of the Strongylocentrotus group is 0.062 and excepted S. nudus of Strongylocentrotus group is 0.041 .
Average of between S. pallidus and Allocentrotus is 0.045 , which was lower than average of the Strongylocentrotus group, and between S. pallidus and S. droebachiensis dis- 
Table 4. Interspecific pairwise $(p)$ distance values among six species of genus Strongylocentrotus with an outgroup (Heliocidaris crassispina) based on partial sequences of mtDNA COI gene, which determined by the Kimura 2-parameter model

\begin{tabular}{|c|c|c|c|c|c|c|c|c|c|c|c|c|}
\hline Species & 1 & 2 & 3 & 4 & 5 & 6 & 7 & 8 & 9 & 10 & 11 & 12 \\
\hline \multicolumn{13}{|l|}{ 1. S. pallidus $(A)$} \\
\hline 2. S. pallidus (B) & 0.005 & & & & & & & & & & & \\
\hline 3. S. pallidus (C) & 0.005 & 0.001 & & & & & & & & & & \\
\hline 4. S. pallidus (D) & 0.004 & 0.001 & 0.001 & & & & & & & & & \\
\hline 5. S. pallidus (E) & 0.000 & 0.004 & 0.005 & 0.005 & & & & & & & & \\
\hline 6. S. pallidus (HM543071)a & 0.002 & 0.004 & 0.005 & 0.005 & 0.002 & & & & & & & \\
\hline 7. S. droebachiensis (HM542394) & 0.039 & 0.038 & 0.039 & 0.039 & 0.039 & 0.038 & & & & & & \\
\hline 8. S. intermedius & 0.081 & 0.080 & 0.081 & 0.081 & 0.081 & 0.081 & 0.083 & & & & & \\
\hline 9. S. nudus & 0.139 & 0.134 & 0.136 & 0.136 & 0.139 & 0.136 & 0.127 & 0.124 & & & & \\
\hline 10. S. polyacanthus (EU700091) & 0.065 & 0.063 & 0.065 & 0.065 & 0.065 & 0.065 & 0.056 & 0.070 & 0.125 & & & \\
\hline 11. A. fragilis (HM473956) & 0.046 & 0.045 & 0.043 & 0.043 & 0.046 & 0.046 & 0.044 & 0.084 & 0.137 & 0.066 & & \\
\hline 12. H. crassispina & 0.214 & 0.216 & 0.214 & 0.214 & 0.214 & 0.216 & 0.213 & 0.205 & 0.188 & 0.215 & 0.211 & \\
\hline
\end{tabular}

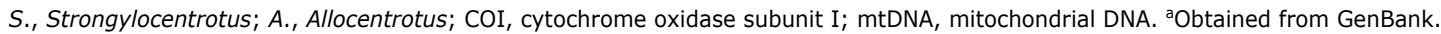

tance (=0.039) was lower than the Strongylocentrotus group average.

\section{DISCUSSION}

Two species of Strongylocentrotus (S. intermedius and $S$. nudus) were previously reported (Shin, 2011). In this study, S. pallidus is newly reported, which has distinct characteristics compared with two species: external figure, pedicellariae and number of pore-pairs in an arc. Strongylocentrotus pallidus has various range of test height; the range of height/diameter of Korean specimens is $38.2-50.0 \%$ and range of peristome/diameter is $31.6-35.7 \%$ (Table 3 ). However, Mortensen (1943) described the range of peristome/diameter as $31.6-45.0 \%$. Thus, we divided the three groups based on the test height: Group- 1 (flattened form) $=S$. pallidus (A), Group-2 (low-hemispherical form) $=S$. pallidus (B)-(D) and Group -3 (hemispherical form) $=S$. pallidus $(\mathrm{E})$. Korean specimens of $S$. pallidus revealed as identical with $S$. pallidus of GenBank. According to the results of phylogenetic analysis and genetic distance (Figs. 2, 3, Table 4). In the phylogenetic tree, S. pallidus group divided by two clades (Figs. 2, 3); S. pallidus (A), (E) and S. pallidus (B)-(D). But, that is not a significant cladogram, because the intraspecific $p$-distance average value is only 0.003 and is much lower than other interspecific $p$-distances (Table 4).

Strongylocentrotus pallidus is very similar with $S$. droebachiensis and can only be discriminated by rather impalpable differences (Vasseur, 1951; Swan, 1962; Jensen, 1974; Vader et al., 1986). For that reason, it has been included in S. droebachiensis (Mortensen, 1943). In these phylogenetic results, S. pallidus and $S$. droebachiensis showed rather close relationships (Table 4); $p$-distance value is only 0.039 , which is lower than average of Strongylocentrotus (0.062) and in phylogenetic tree, $S$. pallidus were branched off close to $S$. droebachiensis. Thus, echinoid specimens are unrecorded species examined in Korea by determining on the basis of the morphological and molecular evidences. Recently, they were divided from each other on the basis of morphological characters within populations and between geographical districts, genetic differences and capacity for hybridization (Vasseur, 1951; Jensen, 1974; Vader et al., 1986; Biermann et al., 2003).

Mortensen (1943) reported that Allocentrotus fragilis is very unlike any of the true species of Strongylocentrotus. However, previous studies (Strathmann, 1979; Biermann et al., 2003) and our phylogenetic results (Figs. 2, 3) show rather close relationships between $A$. fragilis and the species of Strongylocentrotus. The taxonomical position of A. fragilis needs to be consider in a further study.

\section{REFERENCES}

Agassiz A, Clark HL, 1907. Preliminary reports on the Echini collected in 1906, from May to December among the Aleutian Islands, in Bering Sea, and along the coasts of Kamtchatka, Sakhalin, Korea, and Japan, by the U.S. Fish Commission steamer "Albatross" in charge of Lieut. Commander L. M. Garrett, U. S. N., commanding. Bulletin of the Museum of Comparative Zoology, Harvard, 51:109-139.

Bazhin A, 1998. The sea urchin genus Strongylocentrotus in the seas of Russia: taxonomy and ranges. In: Proceedings of the 9th International Echinoderm Conference (Eds., Mooi R, Telford M). Echinoderms, San Francisco, CA, pp. 563566.

Bidenkap O, 1899. Tromsosundets Echinodermer. Troms $\emptyset$ Museums Aarshefter, 20:104-112. 
Biermann CH, Kessing BD, Palumbi SR, 2003. Phylogeny and development of marine model species: strongylocentrotid sea urchins. Evolution and Development, 5:360-371.

Clark HL, 1912. Hawaiian and other Pacific echini. The Pedinidae, Phymosomatidae, Stomopneustidae, Echinidae, Temnopleuridae, Strongylocentrotidae, and Echinometridae. Memoirs of the Museum of Comparative Zoology, Harvard, 34:338-364.

Döderlein L, 1906. Die polyporen Echinoiden von Japan. Zoologischer Anzeiger, 30:515-521.

Downey ME, 1968. Catalog of recent echinoid type specimens in the U.S. national museum, Smithsonian Institution and the museum of comparative zoology, Harvard University. Bulletin of the United States National Museum, 264:1-99.

D'yakonov AM, 1938. The Echinodermata of Siaukhu Bay (Japan Sea). Reports of the Japan Sea Hydrobiological Expedition of the Zoological Institute, Academy Sciences of the USSR in 1934, Part 1:425-498.

Guindon S, Gascuel O, 2003. A simple, fast and accurate algorithm to estimate large phylogenies by maximum-likelihood. Systematic Biology, 52:696-704.

Hall TA, 1999. BioEdit: a user-friendly biological sequence alignment editor and analysis program for Windows 95/ 98/NT. Nucleic Acids Symposium Series, 41:95-98.

Huelsenbeck JP, Ronquist F, 2001. MRBAYES: bayesin inference of phylogenetic trees. Bioinformatics, 17:754-755.

Jensen M, 1974. The Strongylocentrotidae (Echinoidea), a morphologic and systematic study. Sarsia, 57:113-148.

Kimura M, 1980. A simple method for estimating evolutionary rates of base substitutions through comparative studies of nucleotide sequences. Journal of Molecular Evolution, 16: 111-120.

Knott KE, Wray GA, 2000. Controversy and consensus in asteroid systematics: new insights to ordinal and familial relationships. American Zoologist, 40:382-392.

Kroh A, Mooi R, 2011. World Echinoidea database [Internet]. The world register of marine species (WoRMS), Accessed 20 Sep 2011, <http://www.marinespecies.org/echinoidea>.

Mortensen T, 1943. A monograph of the Echinoidea III. Camarodonta II. Echinidae, Strongylocentrotidae, Parasalenidae, Echinometridae. C. A . Reitzel, Copenhagen, pp. 1-446.

Posada D, 2008. jModelTest: phylogenetic model averaging. Molecular Biology and Evolution, 25:1253-1256.

Ronquist F, Huelsenbeck JP, 2003. MrBayes 3: bayesian phylogenetic inference under mixed models. Bioinformatics, 19:1572-1574.

Ronquist F, Huelsenbeck JP, van der Mark P, 2005. MrBayes 3.1 manual [Internet]. Accessed 17 Apr 2011, <http:// mrbayes.sourceforge.net/mb3.1_manual.pdf>.
Saitou N, Nei M, 1987. The neighbor-joining method: a new method for reconstructing phylogenetic trees. Molecular Biology and Evolution, 4:406-425.

Sars GO, 1871. Nye Echinodermer fra den norske kyst. Forhandlinger i Videnskabssel skabet i Kristiania, Christiania, pp. 1-31.

Shin S, 1998. Echinoderms from Geojedo Island and adjacent sea waters, Korea. Korean Journal of Systematic Zoology, 14:193-205.

Shin S, 2011. Sea urchins: invertebrate fauna of Korea. National Institute of Biological Resources, 32:1-122.

Shin S, Rho BJ, 1996. Illustrated encyclopedia of fauna and flora of the Korea. Vol. 36. Echinodermata. Ministry of Education, Korea, Seoul, pp. 1-780.

Smith AB, 2005. The Echinoid Directory [Internet]. National History Museum, London, Accessed 20 Sep 2011, <http://www. nhm.ac.uk/palaeontology/echinoids>.

Southward EC, Campbell AC, 2006. Echinoderms. Synopses of the British Fauna (New Series), 56:1-272.

Strathmann RR, 1979. Echinoid larvae from the northeast Pacific (with a key and comment on an unusual type of planktotrophic development). Canadian Journal of Zoology, 57:610616.

Swan EF, 1962. Evidence suggesting the existence of two species of Strongylocentrotus (Echinoidea) in the northwest Atlantic. Canadian Journal of Zoology, 40:1211-1222.

Tamura K, Peterson D, Peterson N, Stecher G, Nei M, Kumar S, 2011. MEGA5: molecular evolutionary genetics analysis using maximum likelihood, evolutionary distance, and maximum parsimony methods. Molecular Biology and Evolution, 28:2731-2739.

Tatarenko DE, Poltarous AB, 1992. Affiliation of sea urchins Strongylocentrotus echinoides and Strongylocentrotus sachalinicus with Strongylocentrotus pallidus based on the comparison of their genomes. Russian journal of Marine Biology, 17:168-172.

Vader W, Pederson BSH, Lønning S, 1986. Morphological differences between two closely related sea urchin species, Strongylocentrotus droebachiensis and S. pallidus, in northern Norway (Echinodermata, Echinoidea). Fauna Norvegica Series A, 7:10-14.

Vasseur E, 1951. Strongylocentrotus pallidus (G.O. Sars) and S. droebachiensis (O.F. Müller) distinguished by means of sperm-agglutination with egg-water and ordinary morphological characters. Acta Borealia A, Scientia, 2:1-16.

Received October 9, 2011

Revised October 26, 2011 Accepted November 11, 2011 